\title{
EDUCATIONAL CONCEPTS OF INTERNATIONALISM AND MULTICULTURALISM: HISTORICAL AND PEDAGOGICAL ASPECT
}

\author{
Lyudmyla Kruhlenko \\ Senior Lector, Kryvyi Rih National University, Ukraine \\ e-mail: kruhlenko@knu.edu.ua, orcid.org/0000-0002-0596-6926
}

\section{Summary}

The article is devoted to highlighting the origins of the idea of multiculturalism in the Ukrainian educational environment. The author states the relevance of the problem of multiculturalism for the Ukrainian education system, defines the range of the most discussed scientific problems and states the limited scope of work where the problem of multiculturalism was considered from a historical and pedagogical perspective. In paper the author states the presence of this educational trend in the middle of the twentieth century, which has created certain preconditions for the modern implementation of the concept of multicultural education. The article considers educational internationalism as a dual concept, which, on the one hand, promoted fraternity, commonwealth and mutual respect, and on the other hand, irreconcilability towards representatives of other (non-socialist) political views. Therefore, the author is convinced that it is impossible to identify the ideas of internationalism and multiculturalism in education. International education laid the foundations for the creation of a certain social community on the territory of the USSR, however, both external and internal problems associated with the existence of various nations/ethnic groups were solved exclusively on a class (and therefore irreconcilable) basis. On the other hand, the educational concept of multiculturalism deprives the educational discourse of any enmity, opposition of some groups to others, struggle with each other, instead of promoting the ideas of social tolerance, civic values, mutual respect and cooperation. Recognizing the presence of cultural diversity, multicultural education is based on the recognition of the equality of representatives of different cultures, their importance for the sustainable development of the modern world.

Keywords: internationalism, international education, historical and pedagogical discourse, multicultural education, multicultural upbringing.

DOI https://doi.org/10.23856/3923

\section{Introduction}

Modern education must answer the main question of today - whether a young person is ready to live in an open world, marked by objective processes of globalization, integration and migration (labour, cultural, educational). The difficult task can be solved by taking into account the educational community of national and ethnic diversity of members of society, whose coexistence should be based on the principles of equality and mutual respect, which is possible with the widespread introduction of multicultural education in educational discourse.

The origins of this idea in world space are attributed to the post-war period (mid-20th century). It was when, thanks to historical events on a global scale, there was a significant expansion of national interaction, an increase in migration processes, a change in the ethnic composition of a number of states, which caused the need for cultural dialogue and cooperation between representatives of different nations and ethnic groups. Therefore, the issue 
was actualized, first of all, among foreign scientists, including James A. Banks, P. Batelaan, V. Nike, R. Hanvey and others.

It is an indisputable fact that the idea of multiculturalism has entered the sphere of scientific (in particular pedagogical) discourse relatively recently. Scientists (S. Berezhna, V. Melnyk, I. Omelyanchuk, S. Shandruk, etc.) associate its actualization in the world dimension since the 1980s as a problem of intercultural communication with the development of globalization processes, the development of mass democracy and culture, information explosion of the end of the XX century (influence of mass media, new telecommunication technologies), etc.

In pedagogical discourse, the problem of multicultural education has become the subject of study of the following scientists: R. Agadulin, E. Ananyan, R. Antoniuk, F. Asanova, I. Biletska, I. Bakhov, I. Gaganova, V. Bolgarin, L. Goncharenko, L. Golik, D. Popova, M. Rud, A. Shcherbakova and others. The above list of scientists who deal with the problems of multiculturalism in their works is far from complete. From time to time, new scientific works appear on this issue, which convincingly proves its relevance.

The authors of these publications refer to the experience of Western European countries, as well as those authors who have devoted their scientific research to the study of multicultural education in a particular country. There are significantly fewer works that would reveal the theoretical aspects of the problem, and there are almost no works of the historical and pedagogical direction. However, we are convinced that the latest trends in the development of education (such as multiculturalism) should be developed taking into account the historical and pedagogical experience of a particular country, a particular education system. Only under such conditions can we have the continuity of pedagogical thought and can count on a positive result of the latest educational movements.

Therefore, the aim of the study is to identify the historical and pedagogical preconditions for the emergence of the idea of multiculturalism in domestic education. Such preconditions include the prevailing concept of international education in the middle of the twentieth century in the countries of the socialist camp (to which Ukraine belonged at that time).

Historical and retrospective analysis of the facts and pedagogical views of contemporary educators, their modern interpretation using a hermeneutic approach, became the methodological basis of our study.

\section{Concretization of the concept of "multiculturalism" in the domestic pedagogical discourse}

In defining the key concept of "multiculturalism" in education, first of all, we note that domestic pedagogical thought proceeds by generalizing foreign experience, on the basis of which it offers «its own» definitions of multiculturalism and, in particular, multicultural education. So, G. Rozlutskaya argues that «in multicultural education they understand education aimed at preserving, developing and interacting with the entire diversity of cultural values, norms, patterns and forms of activity that exist in a given society, at transferring this heritage to the younger generation, fostering tolerance and live in a multicultural society» (Rozlutska, 2007: 183). This is just one of the definitions available in domestic pedagogy, however, in our opinion, it clearly illustrates the desire of domestic researchers to combine an approach aimed at preserving traditional values with a desire to implement new values. In our opinion, there are certain internal contradictions that hinder the perception of the versatility of the idea of multiculturalism, and therefore hinder the actual integration of this idea into educational practice. Although at the same time it is worth noting that despite the lack of a stable, 
unambiguous understanding of the concept of "multiculturalism" (in particular in education), there are many examples describing the experience of practical work in this direction.

So, I. Bakhov, Ch. Vei, A. Kovalchuk, T. Charkina indicate that «the terms "polyculturalism","multiculturalism", "manyculturalism" are variants of the same term, during the formation of which the first part of the word "poly-", "multi-", "many-" means the presence of a plural: in this case - cultures» (Charkina, 2017: 139). According to scientists, the difference in terminological designation lies in the first part of the word, different in origin (Greek, Latin, Ukrainian) (Vei, 2018: 30). Researchers see the main difference between polyculturalism and multiculturalism in the fact that the former «supports the idea of communication, exchange, interaction and mutual influence», while the latter "aims at segregation, the creation of the concept of "friends" and "strangers") (Charkina, 2017: 139). In addition, scientists note "territorial" preferences in the use of these terms, when they assert the predominant use of the concept of "multiculturalism" by American scientists, and instead of "the term "polyculturalism" was historically used in Europe (Charkina, 2017: 140).

In this paper we rely on the conceptual approach of I. Bakhov who, comparing the principle of polyethnicity and polyculturalism, makes an important conclusion for our work that "the main idea of the principle of polyculturalism is to recognize the importance of differences (social, political, religious, linguistic, physical, gender, age, professional) between members of an ethnically homogeneous group" (Bakhov, 2017: 44). Other Russian scientists hold actually similar positions. Actually, such a vision of multicultural education was proposed by E. Kuchmenko when she noted that "multicultural education, in its general understanding, is an education for which the key concepts are culture as a universal phenomenon; it is a means to help the individual in overcoming the path from the assimilation of ethnic, national culture to the awareness of the common interests of peoples in their striving for peace, harmony, progress through cultural development" (Kuchmenko, 2017: 240).

So, in the modern sense, multicultural education should be based on the principles of common values, striving for peaceful coexistence, interethnic and interethnic harmony and cultural development. These principles, in our opinion, were actualized in the concept of international education of Soviet Ukraine in the middle of the XX century.

\section{Internationalism as an educational concept}

The origins of this idea date back to the second half of the twentieth century, which is associated with the Marxist theory of nations. From these positions, we turn to the assessment of a particular process by modern researchers. In particular, M. Borisova points out that the original idea was that of K. Marx and F. Engels that "the proletariat has no homeland", and therefore the workers' movement must unite all workers through class solidarity. In the USSR, this idea was developed by the works of V. Lenin and J. Stalin in the concept of the opposition of "proletarian internationalism" and "bourgeois nationalism". According to them, "the realization of equality of all "nations" and languages should have ensured the development of "democratic and socialist elements" of "national cultures", which in the future should have formed an "international culture"" (Borysova 2016: 8). Therefore, under these conditions, proletarian internationalism had the right to maintain the world solidarity of the workers.

We also consider it important that the concept of "proletarian" internationalism gave way to the concept of "socialist" internationalism after the "unification" of the countries of the socialist camp (1955, Warsaw Pact). This term, as scientists point out, began to denote the ideology of cooperation between countries "took the path of socialist transformations and the effective implementation of the advantages of socialism" (Nahorna, 2005: 522). 
From the standpoint of our research, we consider it necessary to emphasize the pedagogical aspect of the phenomenon under consideration, which was significantly generalized and theoretically substantiated in V. Slastionin's thesis paper "Work of the Komsomol on the patriotic and international education of workers" (Moscow, 1955). The scientist considers internationalism a companion of patriotism and asserts an effective force in the patriotic (and therefore international) education of the Komsomol. He argued: "Soviet patriotism is inseparable from proletarian internationalism. The organic combination of socialist patriotism with internationalism is the fundamental position of Marxism-Leninism, the ideological basis of fraternal cooperation and friendship of socialist nations, international solidarity of all working people of countries. A true Soviet patriot is a consistent socialist internationalist. Therefore, patriotic education is inextricably linked with international education" (Slastonin, 1955). Therefore, in the quoted passage there is an obvious combination of patriotism (Soviet with internationalism) and a gradual transition from proletarian internationalism to socialist internationalism.

The impetus for activating the idea of internationalism in the educational space is considered the adoption of the third Program of the CPSU (1961), where, according to J. Brolysh, was emphasized the task of the need to develop proletarian internationalism and socialist patriotism and the development of problems of communist education developing the problems of communist education, which became a "turning point in the study of international education" (Brolysh, 1983). Therefore, the researcher attributes the beginning of the theoretical comprehension of internationalism from the standpoint of its educational impact precisely in the 60s. XX century.

Internationalism, which was understood as "a scientifically grounded ideology of the common interests of the working class of all countries and nations, a sense of solidarity of the working people of all countries, the brotherhood of working people; a certain type of relationship between the national laws of the working class, fraternal socialist countries is manifested in unity, coordination of actions, mutual assistance in struggle and labour" (Anhelov, Luchkovskyi, 1968: 1), was to become the unifying ideology, first of all, of the countries of the socialist camp. Therefore, the class principle was the leading one in internationalism.

The main principles of internationalism also included: solidarity, unity of workers around the world, subordination of national interests to international interests, equality and sovereignty of nations and states, fraternal cooperation, unity of will and action, social progress, etc. (Khromov, 1977: 30). So, this ideology was key in the formation of the Soviet people through systematic ideological work, particularly among young students. It was in this interpretation that the then pedagogical press covered the idea of international education.

\section{Tasks and forms of international education}

The teachers of that time convincingly argued that the task of "improving the international education of young people" (Surnin, 1972: 45), which the USSR leadership set for them (in particular, in the decisions of the XXIV Congress of the CPSU) should be fulfilled, especially in the conditions of "unabated ideological war". Socialist internationalism was opposed to the propaganda of the imperialist countries and nationalism.

Therefore, the tasks of international education were:

- «fostering feelings of love for a socialist homeland, common for all Soviet peoples the Union of Soviet Socialist Republics;

- education of young people in the revolutionary, military and labour traditions of the Soviet people, in the spirit of friendship and brotherhood of the peoples of our country, intransigence to national and racial hostility; 
- the formation of the communist consciousness of young men and women, readiness to stand up at any moment to defend the independence of their multinational Motherland and countries of the socialist community;

- education of youth in the spirit of fraternal solidarity with the working people of the socialist countries, with all peoples, in the spirit of proletarian internationalism, intransigence towards the enemies of communism, the cause of peace and freedom» (Surnin, 1972: 45).

In the conditions of a clear definition of the leading tasks of international education, the main attention of the then teachers was focused on the search for effective forms of its implementation. These forms included: the work of international friendship clubs (IFC), correspondence, conversations, disputes, lectures, reports, holidays, festivals, excursions (fulltime/correspondent), thematic evenings, the release of wall newspapers, etc. We can state that practically all forms of educational work with student youth that were currently possible were involved in international education.

The school became a powerful means of international education through works of art and the content of disciplines that were to show the achievements of the socialist homeland and the countries of the socialist commonwealth; in high school they had to learn to apply the acquired knowledge "in the practice of communist construction". The Minister of Culture of the Ukrainian SSR S. Bezklubenko (1977-1983 yy.) stated the effectiveness of such forms of international education as anniversaries of prominent artists, festivals, world, days, weeks, and decades of literature and art of the union republics (Bezklubenko, 1977; Bezklubenko, 1980). Young people were brought up as "patriots-internationalists". Proletarian internationalism was proclaimed "an important condition for the further development of socialism" (G. Bozhuk, V. Surnin), so considerable attention was paid to the education of student youth in the spirit of internationalism.

Rectorates and heads of departments of higher education institutions were instructed to enter into cooperation agreements with "fraternal universities". Both students and teachers were involved in the practice of communication. In particular, lectures were introduced by foreign teachers (from fraternal countries) in Ukrainian universities. For example, we learn from magazine publications that members of the delegation of the Lviv Polytechnic Institute had the opportunity to read lectures at the Rzeszow Engineering School (Poland) on the topic: "Higher school in the USSR for 50 years of Soviet power." However, at the Lviv University, professors V. Perek (Rzeszow), Shumchak (Warsaw), Urbanchyk (Krakow), Leskiv (Lublin) and others gave lectures (Bozhuk, Surnin, 1975). In addition to mutual lectures, other forms of academic mobility were introduced. In particular, students had the opportunity to practice in the fraternal republics, and foreign students came to Ukraine. This practice training was common in Lviv and Uzhhorod state universities. Such connections were considered "an effective means of educating young people to respect fraternal peoples, a means of ideological hardening" (Bozhuk, Surnin, 1975: 155), and thus an effective means of international education of student youth.

\section{Internationalism and multiculturalism: the possibility of conceptual inheritance}

Therefore, we consider it necessary to highlight a number of aspects that indicate a certain similarity (but not identity) of the concepts of educational internationalism. In particular, the publications of the Soviet period spoke about the unified personality of the "Soviet man", determined the presence of a multinational community that existed on the declared principles of "friendship, brotherhood"; this internationalism had, of course, a militant character, since it provoked a struggle against the "enemies of communism". So international friendship was recognized only between the peoples of the USSR and the peoples of the socialist countries. 
Ethnic originality ("nationalist prejudices", "perverted expression of national feelings") was practically identified with "bourgeois nationalism", and therefore was hostile to Soviet education. The key role in international education was assigned to the school, where various forms of education should be used (Lenin's lessons, Lenin's readings; clubs and rooms of international friendship; correspondence with the youth of fraternal republics and socialist countries) (Surnin, 1972: 47).

At the same time, it was noted that the USSR is inhabited by many peoples ("the Soviet people unites in a single organism socio-ethnic communities of more than 100 nations and nationalities"'(Tyshchenko, 1978: 16), which require their attention from the state. The unity of all Soviet people was affirmed, but "this is not means the withering away of socialist nations and nationalities. On the contrary, now, figuratively speaking, in the sky of socialism, all nations - both large and small - shine like stars of the first magnitude (Tyshchenko, 1978: 16). Therefore, on the one hand, the community (Soviet people) was affirmed, on the other hand, national diversity was stated. This was the problem that they tried to solve by establishing internationalism (first proletarian, then - socialist).

We draw attention to the fact that internationalism (proletarian/socialist) concerned not only external communication with the abroad (socialist), but also with the internal establishment of ties between different republics within the country. However, its warlike nature did not change during the Soviet era and was used against both external and internal "enemies". At the same time, those who tried to declare about what national characteristics of the peoples of the USSR were considered internal enemies. In this regard, L. Nahorna makes a fair remark that "the ideologeme of "socialist internationalism" was widely used by the Soviet leadership and as a tool for levelling the national characteristics of the citizens of the USSR, curbing the national elites in the republics. It was the foundation of the myths imposed on the citizens of the USSR about "the Soviet people as a new historical community of people" and about the "national pride of the Soviet man" (Nahorna, 2005: 522).

On the one hand, international education is aimed at forming a new person (devoid of national prejudices), on the other, the unshakable unity of Soviet patriotism with socialist internationalism was proclaimed. At the same time, they did not reject "love for their native land, native language, for the culture of their people" and argued that "international feelings were formed on national ground" (Baranovych, 1975: 12). We consider the following definition indicative in this direction: "Socialist internationalism as the highest stage in the development of proletarian internationalism is manifested in the love of workers for their homeland, the countries of the socialist community, in the international solidarity of the working class, all working people in the struggle for the victory of the socialist revolution" (Baranovych, 1975: 12). Therefore, the academic community paid great attention to the issue of friendship of the peoples of the USSR, Soviet patriotism and the "development" of the national culture of the republics.

In the articles of this period, we see the increasing role of the Soviet government in the development of the languages of the Soviet republics, their cultural revival. We consider the following statement to be indicative: "Fifty years have passed in conditions when any national culture was able to develop freely and unrestrainedly, unique in its socialist content with all the cultures of the fraternal Soviet peoples, unique in form, bringing its diversity to the multicolour of the whole Soviet culture" (Poltoratskyi, 1967: 1). So, the development of a culture "national in form and socialist in content" allegedly took place. The reality was different. However, international education required the recognition of the above formula. The cultural press of the time continued insisting, that "the Communist Party in its resolutions instilled in the people the concept of multinational culture, internationalism, friendship and 
interaction of peoples, taught to develop its progressive elements in each national culture" (Poltoratskyi, 1967: 2).

Under such conditions, we can state a significant difference between the educational ideas of internationalism and multiculturalism, since the latter notes the recognition of the diversity, uniqueness and value of all ethnic groups and nations, completely rejecting any form of enmity and affirming the key principles of mutual respect and tolerance.

\section{Conclusions}

The above suggests that the understanding of the idea of multiculturalism in a variety of interpretations and the search for its origins in the pedagogical theory of the late twentieth century makes it necessary to turn to the concept of international education, which in its essence touched on issues related to our study of education/upbringing of youth in a multinational Soviet state and was formulated as an idea of "proletarian (later - socialist) internationalism".

Fully sharing the position of modern scientists about the current disappearance of the concept of "international education" and its replacement by "polycultural education", "polyethnic education", "education of interethnic relations" (Liakh, 2012: 237), we consider it necessary to emphasize the impossibility of avoiding the issue of class intransigence of proletarian (socialist) internationalism. This also makes it impossible (internationalism) to fully explicate it on a modern pedagogical thesaurus. In addition, this feature, in our opinion, is key for the concept of internationalism, since it had an ideological direction.

So, we consider imitation of the principle of internationalism by modern education inadmissible, given its class (irreconcilable) character. So, international education, indeed, laid the foundations for the creation of a certain social community on the territory of the USSR, however, both external and internal problems associated with the existence of various nations/ethnic groups were solved exclusively on a class (and therefore irreconcilable) basis. On the other hand, the educational concept of multiculturalism deprives the educational discourse of any enmity, opposition of some groups to others, struggle with each other, instead of promoting the ideas of social tolerance, civic values, mutual respect and cooperation. Recognizing the presence of cultural diversity, multicultural education is based on the recognition of the equality of representatives of different cultures, their importance for the sustainable development of the modern world.

\section{References}

Anhelov, H., Luchkovskyi, R. (1968). Vazhlyva dilianka ideolohichnoi roboty. [An important area of ideological work] Sotsialistychna kultura, 7, 1-3. [in Ukrainian].

Bakhov, D. (2017). Tendentsii rozvytku polikulturnoi osvity u profesiinii pidhotovtsi fakhivtsiv Kanady i SShA (druha polovyna XX - pochatok XXI st.) [Trends in the development of multicultural education in the training of specialists in Canada and the United States (second half of $X X$ - early XXI century)] [in Ukrainian].

Baranovych, S. (1975). Radianska kultura i vykhovannia trudiashchykh u dusi sotsialistychnoho internatsionalizmu ta radianskoho patriotyzmu. [Soviet culture and education of workers in the spirit of socialist internationalism and Soviet patriotism]. Sotsialistychna kultura, 11, 12-13. [in Ukrainian].

Bezklubenko, S. (1980). Vazhlyva dilianka ideolohichnoi roboty [An important area of ideological work]. Sotsialistychna kultura, 4, 1-4. [in Ukrainian].

Bezklubenko, S. (1977). U rozkviti dukhovnykh syl [In the prime spiritual strength]. Sotsialistychna kultura. 1977. 12. C. 2-5. [in Ukrainian]. 
Borysova, M. (2016). Analyz formyrovanyia dyskursa ynternatsyonalyzma $v$ brede bolshevykov $v$ nachale XX veka [Analysis of the formation of the discourse of internationalism in the delirium of the Bolsheviks at the beginning of the twentieth century]. Vestnyk Kemerovskoho hosudarstvennoho unyversyteta, 1(65), 7-10. [in Russian].

Bozhuk, H., Surnin, V. (1975). Rol mizhvuzivskoho spivrobitnytstva sotsialistychnykh krain $v$ internatsionalnomu vykhovanni molodi [The role of interuniversity cooperation of socialist countries in the international education of youth]. Zmitsnennia svitovoi sotsialistychnoi systemy - torzhestvo idei proletarskoho internatsionalizmu : materialy respublikanskoi naukovo-teoretychnoi konferentsii. Uzhhorod, 153-155. [in Ukrainian].

Brolysh, Ya. (1983). Formyrovanye ynternatsyonalystycheskoi zrelosty na эtape razvytoho sotsyalyzma (Teoretyko-metodolohycheskyi aspekt) [Formation of internationalist maturity at the stage of developed socialism (Theoretical and methodological aspect)]. Riha, 436. [in Ukrainian].

Charkina, T. (2017). Teoretychni aspekty formuvannia polikulturnykh kompetentsii v suchasnomu osvitnomu prostori [Theoretical aspects of the formation of multicultural competencies in the modern educational space] Visnyk Kharkivskoho natsionalnoho pedahohichnoho universytetu imeni H. S. Skovorody. Filosofiia, 47(2), C. 138-146. [in Ukrainian].

Khromov, S. (1977). Ynternatsyonalyzm y patryotyzm: ystoryia y sovremennost. [Internationalism and patriotism: history and modernity]. [in Russian].

Kuchmenko, E. (2017). Multykulturne vykhovannia - miltykulturna vzaiemodiia liudskykh tsinnostei (istoriohrafichnyi ohliad) [Multicultural education - multicultural interaction of human values (historiographical review)]. Literatura ta kultura Polissia. Seriia «Istorychni nauky», 87, 232-242. [in Ukrainian].

Liakh, O. (2012). Vidobrazhennia pytan internatsionalnoho vykhovannia u naukovo-pedahohichnomu misiachnyku «Radianska shkola» (50-80-ti roky XX st.) [Reflection of issues of international education in the scientific and pedagogical month "Soviet School" (50-80s of the XX century)]. Naukovyi visnyk Melitopolskoho derzhavnoho pedahohichnoho universytetu. Seriia «Pedahoihka», 8, 229-235. [in Ukrainian].

Nahorna, L. (2005). Internatsionalizm. [Internationalism] Entsyklopediia istorii Ukrainy. 521-522. [in Ukrainian].

Poltoratskyi, O. (1967). V odnomu pyshnomu vinku (pro vzaiemozviazky kultur bratnikh narodiv SRSR [In one magnificent wreath (about the interrelationships of the cultures of the fraternal peoples of the USSR)]. Sotsialistychna kultura, 6, 1-3. [in Ukrainian].

Rozlutska, H. (2007). Rol polikulturnosti u vykhovanni ukrainskoi molodi]. [The role of multiculturalism in the education of Ukrainian youth]. Pedahohichni nauky, 45, 181-185. [in Ukrainian].

Slastonin, V. (1955). Robota komsomolu z patriotychnoho ta internatsionalnoho vykhovannia trudiashchykh [The work of the Komsomol on patriotic and international education of workers]. Moskva, 1955 [in Ukrainian].

Surnin, V. (1972). Internatsionalizm - vazhlyvyi pryntsyp komunistychnoho vykhovannia molodi [Internationalism is an important principle of communist education of young people]. Materialy pershoi oblasnoi konferentsii molodykh vchenykh Zakarpattia, prysviachenoi 50-richchiu utvorennia Soiuzu RSR. Uzhhorod, 43-49. [in Ukrainian].

Tyshchenko, V. (1978). Narod - odnodumets, narod - internatsionalist [The people are likeminded, the people are internationalists]. Sotsialistychna kultura, 1978, 6, 16-17. [in Ukrainian]. Vei, Ch (2018). Mizhkulturne vykhovannia studentiv vyshchykh navchalnykh zakladiv zasobamy muzyky [Intercultural education of students of higher educational institutions by means of music]. [in Ukrainian]. 